\title{
Black carbon record based on a shallow Himalayan ice core and its climatic implications
}

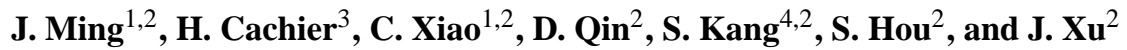 \\ ${ }^{1}$ Institute of Climate System, Chinese Academy of Meteorological Sciences, Beijing 100081, China \\ ${ }^{2}$ State Key Laboratory of Cryospheric Sciences, Cold and Arid Regions Environmental and Engineering Research Institute, \\ Chinese Academy of Sciences, Lanzhou 730000, China \\ ${ }^{3}$ Laboratoire des Sciences du climat et de l'Environnement, CEA-CNRS-University Versailles St Quentin, Gif-sur-Yvette \\ 91198, France \\ ${ }^{4}$ Institute of Tibetan Plateau Research, Chinese Academy of Sciences, Beijing 100085, China
}

Received: 30 August 2007 - Published in Atmos. Chem. Phys. Discuss.: 10 October 2007

Revised: 24 January 2008 - Accepted: 7 February 2008 - Published: 6 March 2008

\begin{abstract}
A continuous measurement for black carbon (hereafter "BC") in a $40 \mathrm{~m}$ shallow ice core retrieved from the East Rongbuk Glacier (hereafter "ERG") in the northeast saddle of Mt. Qomolangma (Everest) provided the first historical record of $\mathrm{BC}$ deposition during the past $\sim 50 \mathrm{yrs}$ in the high Himalyas. Apparent increasing trend (smooth average) of BC concentrations was revealed since the mid-1990s. Seasonal variability of $\mathrm{BC}$ concentrations in the ice core indicated higher concentrations in monsoon seasons than those in non-monsoon seasons. Backward air trajectory analysis by the HYSPLIT model indicated that South Asia's BC emissions had significant impacts on the BC deposition in the Mt. Qomolangma (Everest) region. The estimated average atmospheric $\mathrm{BC}$ concentration in the region was about $80 \mathrm{ng} \mathrm{m}^{-3}$ during 1951-2001. And it was suggested BC emitted from South Asia could penetrate into the Tibetan Plateau by climbing over the elevated Himalayas. A significant increasing trend of the radiative forcing simulated by the SNICAR model appeared since 1990, which even exceeded $4.5 \mathrm{~W} \mathrm{~m}^{-2}$ in the summer of 2001. It was suggested that this amplitudes of $\mathrm{BC}$ concentrations in the atmosphere over the Himalayas and consequently in the ice in the glaciers could not be neglected when assessing the dual warming effects on glacier melting in the Himalayas.
\end{abstract}

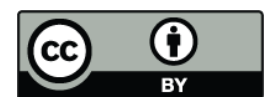

Correspondence to: J. Ming (mingjing@mail.iggcas.ac.cn)

\section{Introduction}

$\mathrm{BC}$ plays an important role in the earth climate system. BC particles suspended in the atmosphere could result in very complex radiative effects by acting as the light absorber and veil (e.g. Jacobson, 2004a). Although there were many uncertainties on this issue, negative impact of short term cooling but long term warming the atmosphere dominated the popular views (e.g. Jacobson, 2004b). A recent highlight on $\mathrm{BC}$ climate effect was that $\mathrm{BC}$ deposited in snow and ice surface could absorb the sunlight largely and consequently reduce the albedo intensely so as to accelerate the melting of snow cover and sea ice (e.g. Hansen and Nazarenko, 2004; Jacobson, 2004a).

Alpine glaciers and polar ice sheets are excellent archives for documenting dry and wet depositing constituents in the atmosphere. BC measurements in snow and ice had been conducted by some previous studies since the 1980s (e.g. Chýlek et al., 1987, 1995; Cachier and Pertuisot, 1994), and a new technique for measuring $\mathrm{BC}$ in a Greenland ice core with better resolution than previous methods was recently reported, describing a significant enhanced climate forcing on Arctic ice caused by the 20th-century industrial BC emissions (McConnell et al., 2007). These papers focused on the issue on the Arctic haze and therefore its consequent climatic and environmental significances. However, historical records for $\mathrm{BC}$ deposition recovered from ice cores in midlow latitudes were very few till now, and there were two reports on the carbonaceous particle concentrations in ice cores both drilled from the glaciers located in Mt. Alps. One reported $\mathrm{BC}$ concentration increased by a factor of 3.7 from

Published by Copernicus Publications on behalf of the European Geosciences Union. 




Fig. 1. Location map of ERIC2002C drilling site.

$22 \mu \mathrm{g} \mathrm{kg}^{-1}$ during $1755-1890$ to $82 \mu \mathrm{g} \mathrm{kg}^{-1}$ during 1950 1975 (Lavanchy et al., 1999), and the other showed BC concentration increased from $15 \mu \mathrm{g} \mathrm{kg}^{-1}$ during $1650-1870$ to $27 \mu \mathrm{g} \mathrm{kg}^{-1}$ during 1870-1940 (Jenk et al., 2006).

The Himalayas is located on the south margin of the Tibetan Plateau (hereafter "TP") and stretches $2500 \mathrm{~km}$ from west to east, spanning the middle and upper layers of the troposphere. And it may be an effective barrier to restrict the exchange of air masses between the TP and the Indian subcontinent carried by monsoons in summers and by westerly in winters (Nieuwolt, 1977). The ERG is located in the northeast saddle of Mt. Qomolangma (Everest) in the central Himalayas. Previous studies on the ice core records recovered here had revealed plenty of credible information on climate change and environment (e.g. Qin et al., 2002; Kang et al., 2002). South Asia has been a fast-developing region with large $\mathrm{BC}$ emissions in recent years, for example, in the 1990s the BC emission in South Asia was $563.9 \mathrm{Gg}$, accounting for $12.3 \%$ of total $\mathrm{BC}$ emission throughout the world (Bond et al., 2007), and South Asia is also known as a home to the Asian Brown Cloud (hereafter "ABC") (e.g. Ramanathan et al., 2001a, 2007). And ABC, which covers most of the Arabian Sea, the Bay of Bengal, and South Asia, occurs every year and extends from November through May. The brownish haze is composed of a 3-km-thick mixture of anthropogenic sulfates, nitrates, organics, black carbon, dust and fly ash particles, and natural aerosols such as sea salt and mineral dust (Ramanathan and Ramana, 2003). In-situ measurements of aerosol chemistry from aircrafts, ships, and surface stations found that anthropogenic sources (e.g. biomass burning, fossil-fuel combustion) contributed as much as $75 \%$ to the observed aerosol concentration (e.g. Ramanathan et al., 2001b; Lelieveld et al., 2001). As the hinterland abutted by Central/East/South Asia, the atmospheric environment over the TP might be under the impacts of the polluted air masses derived from these regions. $\mathrm{BC}$ deposition information could be archived frozen in the ERG. And yet no data on BC deposition in the glaciers was obtained from this site till now. In this work, we tried to recover a $\mathrm{BC}$ depositing history via a shallow ice core (hereafter "ERIC2002C") drilled from the ERG in 2002.

\section{Experimental methods}

\subsection{Ice coring}

ERIC2002C was retrieved in a dry hole in the summer of 2002. The drilling site was located in the Repula Col $\left(28^{\circ} 01^{\prime} 12^{\circ} \mathrm{N}, 86^{\circ} 57^{\prime} 36^{\circ} \mathrm{E}\right.$, and $6500 \mathrm{~m}$ a.s.l.) of the ERG near Mt. Qomolangma (Fig. 1). A repeating survey with a Sokkia GSS1A Global Positioning System (accuracies of $\pm 5 \mathrm{~mm}$ over distance up to $10 \mathrm{~km}$ ) in 1998 and 2002 did not identify horizontal movement at the drilling site (Hou et al., 2007). At the saddle of the ERG, the present average annual net accumulation was about $500 \mathrm{~mm}$ water equivalent as determined from snow pits and a stake accumulation network established during a reconnaissance in May of 1998. Prior to drilling, a $1.5-\mathrm{m}$ deep snow pit was dug to remove the snow/firn above the borehole. The ice core was $40.8 \mathrm{~m}$ in length and $9.4 \mathrm{~cm}$ in diameter and was sealed in polyethylene bags in sections of 50 to $115.5 \mathrm{~cm}$. At the same time, the other two ice cores with the lengths of $108.83 \mathrm{~m}$ and $95.80 \mathrm{~m}$ (named "ERIC2002A" and "ERIC2002B", respectively) were extracted together at very near sites. The borehole temperature of ERIC2002A ranged from a minimum of $-9.6^{\circ} \mathrm{C}$ at $20 \mathrm{~m}$ to a maximum of $-8.9^{\circ} \mathrm{C}$ at the bottom. The low temperature throughout the borehole indicated that the information of atmospheric depositions here could be preserved. We maintained the ice core in frozen condition during the transportation and storage time.

The deepest section of ERIC2002C was used to analyze culturable bacteria (Zhang et al., 2007). Each section of the left was split into two halves axially. One half was analyzed for $\delta^{18} \mathrm{O}$ isotope and soluble major ions $\left(\mathrm{Na}^{+}, \mathrm{K}^{+}\right.$, $\mathrm{Mg}^{2+}, \mathrm{Ca}^{2+}, \mathrm{Cl}^{-}, \mathrm{NO}_{3}^{-}$, and $\mathrm{SO}_{4}^{2-}$ ). The measurements for $\delta^{18} \mathrm{O}$ and ions were performed at the State Key Laboratory of Cryospheric Sciences (SKLCS) following the methods of previous studies (e.g. Tian et al., 2003; Xiao et al., 2004). And in this work the left half was used to analyze BC. 


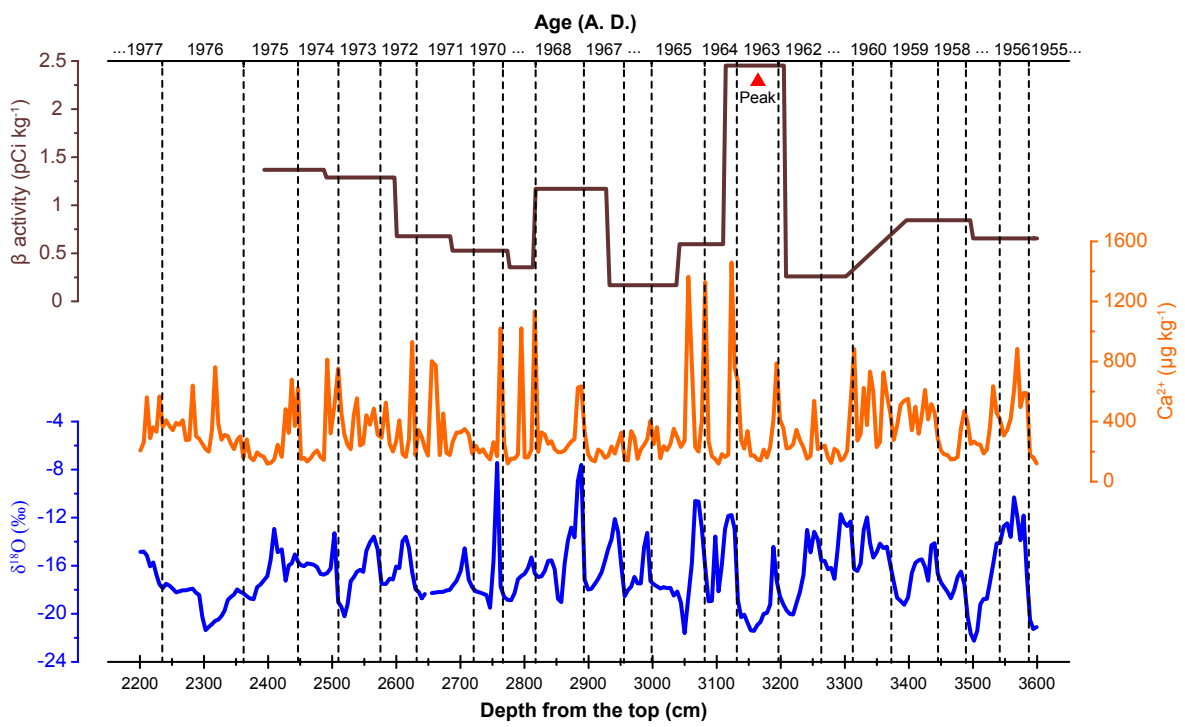

Fig. 2. The dating of ERIC2002C (episode), where $\beta$ activity peak showed in 1963, and calcium and $\delta^{18}$ O showed seasonal variability (it could be observed that less negative $\delta^{18} \mathrm{O}$ values in non-monsoon seasons and more negative $\delta^{18} \mathrm{O}$ values in monsoon seasons).

\subsection{Ice core dating}

Amount effect in the precipitations near Mt. Qomolangma caused less negative $\delta^{18} \mathrm{O}$ values in non-monsoon seasons and more negative $\delta^{18} \mathrm{O}$ values in monsoon seasons as recorded in the ice cores of the ERG (Qin et al., 2002; Kang et al., 2002). Calcium was suggested to be the most definitive ion for precise dating due to its striking high concentrations and low concentrations displayed in non-monsoon and monsoon seasons, respectively, based on snow chemistry data from both fresh snow and snow pit samples (Kang et al., 2004). Therefore we dated ERIC2002C by counting the seasonal variability of $\delta^{18} \mathrm{O}$ and $\mathrm{Ca}^{2+}$ profiles, simultaneously considering the annual net water accumulation. The result was further verified by the $\beta$ activity horizon produced by the atmospheric thermonuclear test in 1963 (Fig. 2). Subtracting one year of the snow pit covering ERIC2002C, the ice core was dated to be 50 yrs old (1951-2001 AD). We estimated a dating error of \pm 1 year throughout the whole ice core.

\subsection{Sample preparation}

Although $\mathrm{BC}$ measurement in ice required rather large amounts of sample, sufficient sample guaranteed we could perform a continuous measurement for BC concentrations in ERIC2002C. Four testing samples sectioned randomly from ERIC2002C were measured for BC aforehand to consider what was the proper volume needed for each sample. The $\mathrm{BC}$ masses of these testing samples gave us a clue that 70 to $500 \mathrm{~g}$ per sample was the best weight for carbon analysis, giving 5 to $10 \mu \mathrm{g} \mathrm{BC}$ on the filter deposit. ERIC2002C were divided into sections with expected weights, and 143 samples were obtained aggregately.

All the samples were prepared in the laminar flow cabinet of the inner clean room of 100-class (numbers of particles larger than $0.5 \mu \mathrm{m}$ in $1 \mathrm{ft}^{3}$ air are less than 100) in a low-temperature room $\left(-20^{\circ} \mathrm{C}\right)$. A series of scraping operations were performed on the samples. A pre-cleaned lathe was used to peel the skin of 1-2 cm thickness of each sample. And the next outer layer of approximate $1 \mathrm{~cm}$ thickness of each sample was removed by scraping manually with a pre-cleaned stainless steel blade. Then the ice samples were stored in pre-cleaned glass jars with covers and kept at low temperature until filtration.

Filtering was operated in the warm clean room of 100class. Warm water bath was used to shorten the time of melting. Once there was some melted water of around 1-cm depth in the container, the samples were allowed to melt at the room temperature and manually stirring the container could further favor the process. This process was limited within $4 \mathrm{~h}$ to avoid developing extra bacteria. Immediately after melting and prior to filtration, the bottles with melted samples were submitted to ultra sounding for $15 \mathrm{~min}$ in order to avoid loss of particles which might have attached to the walls of the containers. The samples were weighed with a cylinder $( \pm 1 \mathrm{~mL})$ and then filtered through circular quartz fiber filters with a pore size of $1 \mu \mathrm{m}$ (Whatman ${ }^{\circledR}$ QMA). The filters were $25 \mathrm{~mm}$ in diameter and were preheated for $24 \mathrm{~h}$ in an oven at $600^{\circ} \mathrm{C}$. Filtration was performed using a glass unit and resulted in a circular spot of $12 \mathrm{~mm}$ in diameter. A hand vacuum pump was used to accelerate filtering the melted samples. After filtration, hydrochloric acid (2-4\%) was put on the filter and passed through. Acidification step duration of 


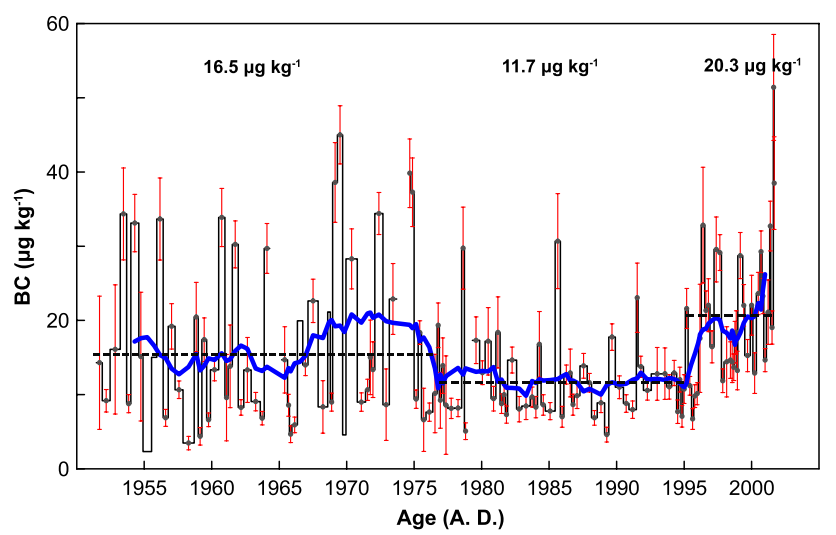

Fig. 3. The time series of $\mathrm{BC}$ concentrations for the samples sectioned from ERIC2002C (each step represented one sample), where the error bars were presented as the solid red lines with middle grey dots, and the thick solid blue curve was the smooth average. And three average BC concentration levels during 1951-1975, 19751994, and 1995-2002 were showed as the dashed lines with values above in the plot.

$15 \mathrm{~min}$ at least was necessary to remove carbonates which might if any, overestimate $\mathrm{BC}$ contents. The containers were rinsed four times with ultra pure water (Milli-Q, 18.2 M $\Omega$ ) to ensure complete transfer of the carbonaceous particles to the filter. Following above filtering procedure, the attachment of particles on the glassware walls was found to be less than 5\% and the fiber filter efficiency for the capture of particles was better than 97\% (Cachier and Pertuisot, 1994). Finally, the filters would be moved into clean Petri-slides (Millipore ${ }^{\circledR}$ ) and set in clean cabinet to let them dry. In addition, 12 blank filters were made at the filtration intervals at times by passing through $\mathrm{HCl}$ solution for $15 \mathrm{~min}$ at least and the rinsing solution after washing the blank bottles with ultra pure water.

\subsection{BC measurement}

Filters were analyzed at the Laboratoire des Sciences du Climat et l'Environnement (LSCE). Pre-combustion was necessary to eliminate the organic carbon (hereafter "OC") and minimize any "cross-over" effect between $\mathrm{OC}$ and $\mathrm{BC}$. BC and OC separation was obtained following the analytical protocol set up for aerosols (Cachier et al., 1989) and adapted for snow and ice samples (Cachier and Pertuisot, 1994). Sampleloaded filters were punched with a pre-cleaned unit $(14 \mathrm{~mm}$ of the diameter) to remove the outer loop. Before moving the filters into the analyzers, they were put in an oven for around $20 \mathrm{~min}$ at $70^{\circ} \mathrm{C}$ to eliminate the water vapor and volatile organic compounds likely adhered to them when they were between pre-combustion and analysis. According to the visual grey level of filters' color, they were divided into two batches, which were the heavily loaded filters and the lightly loaded ones, respectively. The first batch including 55 samples was submitted to a coulometric titration-based analy- sis (using the Ströhlein Coulomat $702 \mathrm{C}^{\circledR}$ with the detection limit of $3 \mu \mathrm{g}$ Carbon and the precision of $0.02 \mu \mathrm{g}$ Carbon), the second batch including 88 samples was submitted to a thermo-optical analysis (using the thermo-optical transmission carbon analyzer System by Sunset Lab ${ }^{\circledR}$, with the detection limit of $2 \mu \mathrm{g}$ Carbon per $\mathrm{cm}^{2}$ ), and 12 blank filters were submitted to the Ströhlein Coulomat $702 C^{\circledR}$ in a lump for measuring their $\mathrm{BC}$ mass. And the range of $\mathrm{BC}$ mass for the filters submitted to the Ströhlein Coulomat $702 \mathrm{C}^{\circledR}$ was $1.80-21.69 \mu \mathrm{g}$ with an average of $9.03 \pm 4.74 \mu \mathrm{g}$ (the filters with BC loading heavier than $3 \mu \mathrm{g}$ accounting for $94 \%$ of the first batch of samples), and for the filters submitted to the Sunset ${ }^{\circledR}$ was $1.51-9.50 \mu \mathrm{g}$ with an average of $3.63 \pm 1.36 \mu \mathrm{g}$. The area-average BC mass density of the 12 blank filters was $0.076 \mu \mathrm{g}$ Carbon per $\mathrm{cm}^{2}$, yielding an average blank BC loading for each sample was $0.12 \mu \mathrm{g}$ Carbon, which would be subtracted from the samples.

\section{Results and discussion}

3.1 General varying trend and seasonal variation of $\mathrm{BC}$ concentrations

Bond et al. (2007) reported a historical record of BC emissions from different regions in the world, which indicated an increasing trend of BC emission in South and Central Asias as the adjacent regions to the Himalayas during the past $150 \mathrm{yrs}$. And the ERG preserved the concentration variations of $\mathrm{BC}$ deposit in ERIC2002C as showed in Fig. 3. BC record during the last $50 \mathrm{yrs}$ could be divided into three stages based on the different concentration levels, which were 1951-1976, 1976-1994, and 1995-2002, respectively. During 1951-1976, BC concentrations had the mean of $16.5 \pm 10.8 \mu \mathrm{g} \mathrm{kg}^{-1}$ and showed large fluctuations, especially for the later part (1966-1976) when significant high concentrations appeared in the smooth curve. During 19771994, BC concentrations had the mean of $11.7 \pm 5.4 \mu \mathrm{g} \mathrm{kg}^{-1}$ were quite low and stable. However, during 1995-2002 when the highest BC concentration level $\left(20.3 \pm 9.2 \mu \mathrm{g} \mathrm{kg}^{-1}\right)$ was displayed, there was a significant increasing trend for $\mathrm{BC}$ concentrations, which exceeded $50 \mu \mathrm{g} \mathrm{kg}^{-1}$ in the summer of 2001.

Although the time resolution of the $\mathrm{BC}$ record throughout ERIC2002C was not high enough for investigating the seasonal cycles of $\mathrm{BC}$ concentrations, distinguished seasonal variation of $\mathrm{BC}$ concentrations between monsoon and nonmonsoon seasons could be observed in the top sections of the ice core, which covered 2000-2001 with relatively higher resolution for BC. In Mt. Qomolangma region, the annual period from June to October was thought as the Indian summer monsoon dominating time for the synoptic situation (Shen, 1975). BC concentrations in the monsoon seasons were significantly higher than those in the non-monsoon seasons, as showed in Fig. 4. 


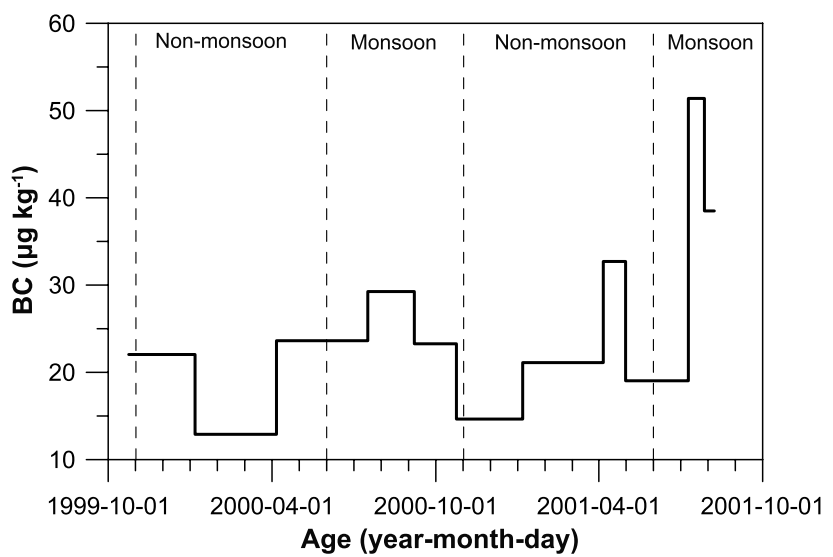

Fig. 4. A portion of BC concentrations covering 2000-2001 with relatively higher time resolution in ERIC2002C, where seasonal variability showed $\mathrm{BC}$ concentrations in monsoon seasons were higher than those in non-monsoon seasons.

\subsection{Estimated atmospheric $\mathrm{BC}$ concentrations over the} ERG

BC concentrations in ERIC2002C might provide us an approach to estimate the atmospheric $\mathrm{BC}$ concentration level over the ERG during the past 50 yrs. At lower elevations, apportioning between dry and wet depositions for BC aerosol must be considered when doing the estimation. Some modelling studies simulated the mean ratio of wet/total removal of $\mathrm{BC}$ from the atmosphere and suggested wet deposition was the dominate sink for BC. For example, the AeroCom (Aerosol Comparisons between Observations and Models) project derived a mean of $79 \%$ for wet/total removal ratio from running 14 global aerosol models (Textor et al., 2006), and Croft et al. (2005) run the CCCma AGCM (the 4th generation Canadian Centre for Climate modelling and analysis Atmospheric General Circulation Model) and obtained a very close value of $75 \%$ to the former. However, over the ERG with such an extremely high elevation and a big annual net accumulation with the average of $500 \mathrm{~mm}$ water equivalent, wet deposition might dominate $\mathrm{BC}$ aerosol removal from the atmosphere, and we presumed that nearly all of the BC in ERIC2002C was wet-deposited and did the estimation for atmospheric $\mathrm{BC}$ concentrations from the ice via wet scavenging ratio method.

We used a transformed equation

$C_{a}=\rho_{a} \times C_{s} / \omega(\#)$

based on the work by Davidson et al. (1993) to estimate $\mathrm{BC}$ concentrations in the atmosphere, where $C_{a}$ was species concentration $\left(\mathrm{ng} \mathrm{m}^{-3}\right)$ in the atmosphere, $\rho_{a}$ was air density $\left(\mathrm{g} \mathrm{m}^{-3}\right)$ after correcting for the standard temperature and pressure $\left(0^{\circ} \mathrm{C}\right.$ and $\left.1013 \mathrm{hPa}\right), C_{s}$ was species concentration $\left(\mathrm{ng} \mathrm{g}^{-1}\right.$ ) in snow, and $\omega$ was the scavenging ratio for a specific species by snow falls.
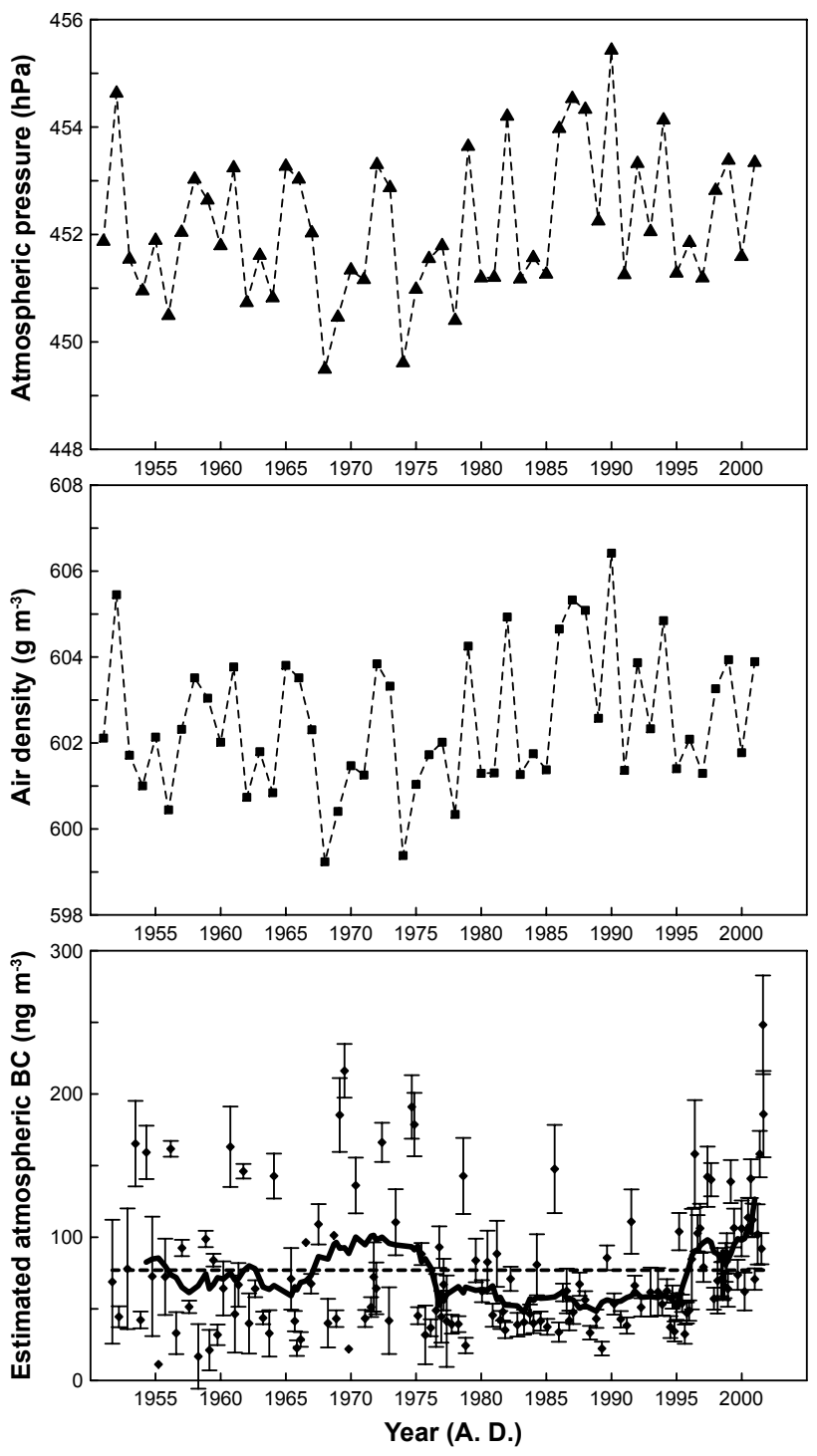

Fig. 5. The variability of estimated yearly mean air pressures (the top plot) and air densities (the middle plot) over the ERG during 1951-2001, and the time series of estimated atmospheric BC concentrations (with error bars) over the ERG during the past $50 \mathrm{yrs}$ (the bottom plot), where the thick solid thick curve represented the smooth average, and the dashed line represented the mean level of atmospheric BC concentrations $\left(\sim 80 \mathrm{ng} \mathrm{m}^{-3}\right)$.

The value of $\omega$ was estimated by several previous studies, for example, at 160 by Clarke and Noone (1985), at $97 \pm 34$ by Noone and Clarke (1988) for Arctic, and at 150 by Warren and Clarke (1990) for the East Antarctic Plateau. Jacobson (2004a) used a three-dimension global model to estimate $\omega$ at $\sim 125$ as a worldwide mean. The numerical value of 125 was adopted for our estimation, for the measured $\omega$ was unavailable at this site. We obtained a time series of yearly mean atmospheric pressure at the drilling site from 1951 to 2001 after interpolating $6500 \mathrm{~m}$ a.s.l. between the geopotential 


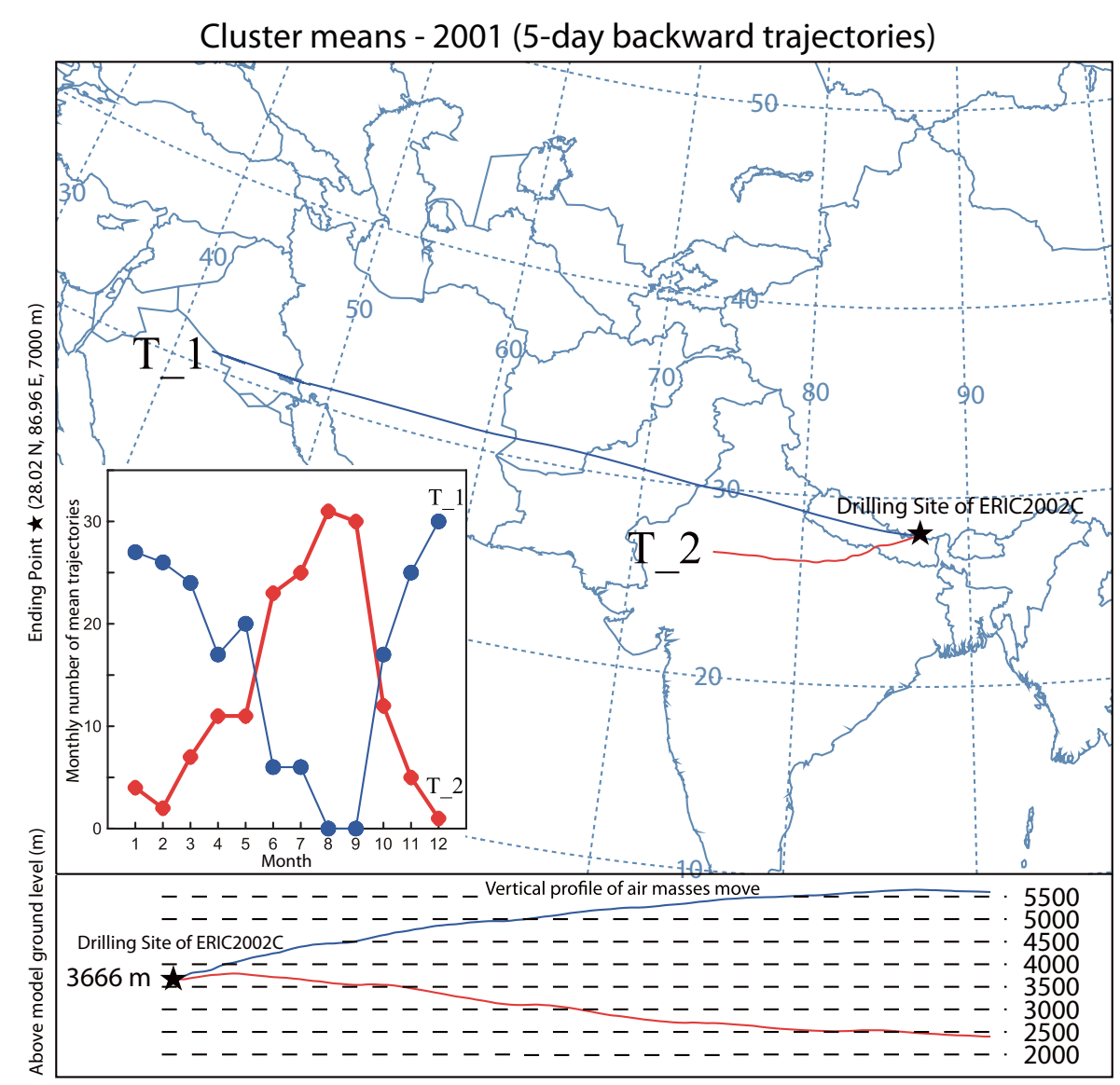

Fig. 6. A typical result of two mean trajectories ending at the drilling site in 2001 simulated by the HYSPLIT 4.8 model. 5-day backward air trajectories each year were simulated with a daily resolution. For each year during 1951-2001, they were clustered using the integrated tool assembled in the model. Generally, two mean trajectories could be derived, in which one was for the long-distance transport ( $\left.\mathrm{T}_{-} 1\right)$, the other was for non-long-distance transport (T_2), and the altitude $(3666 \mathrm{~m})$ represented meters above model ground level. The latter trajectory suggested the air masses transported from South Asia in monsoon seasons, suggested by the seasonal cycle of the numbers of T_1 and T_2 distributed in 12 months of 2001 .

heights of 400 and $500 \mathrm{hPa}$ based on NCEP/NCAR reanalysis data, and then we estimated a time series of yearly mean air density at the drilling site from 1951 to 2001, and therefore we used the equation (\#) to estimate the atmospheric BC concentrations over the ERG during the past 50 yrs (Fig. 5). And the similar varying trend of the atmospheric $\mathrm{BC}$ concentrations with the mean concentration level of $77 \pm 45 \mathrm{ng} \mathrm{m}^{-3}$ over the ERG in the past $50 \mathrm{yrs}$ could be surveyed with the ice $\mathrm{BC}$ concentrations.

3.3 The relationship between atmospheric BC over the ERG and its transport pathways

Previous studies on snow/ice chemistry suggested the atmospheric environment over the high elevated glaciers in the Himalayas was little affected by boundary layer and reflected the deposition of particles of non-vicinity sources (e.g. Wake et al., 1994; Kang et al., 2002). An aerosol study conducted on the ERG in 2003 suggested sulfate, as an indicator of anthropogenic activities originated from South Asia, contributed significant amount to the atmospheric environment over the ERG during the Indian summer monsoon season (Ming et al., 2007). So we precluded significant local BC sources, for the ERG near Mt. Qomolangma was a very remote site.

Air masses over the TP were mainly dominated by polar air masses from the Arctic, continental air masses from central Asia, and maritime air masses from the Pacific and Indian Ocean (Bryson, 1986). And with the alternation of seasons, the dominant air masses varied. During monsoon seasons, the Indian summer monsoons dominated the synoptic regime over the ERG, while the westerlies took their power during non-monsoon seasons (Ye and Yang, 1979). The transport patterns of the air masses were largely different as indicated by the different dominating synoptic situations over the ERG in different seasons. For example, the air masses over the ERG were transported dominantly by Indian summer monsoons and next by westerlies during 
monsoon seasons, and yet they were completely transported by westerlies during non-monsoon seasons. We used the HYbrid Single-Particle Lagrangian Integrated Trajectory (HYSPLIT) model described by Draxler and Hess (1998), to investigate the transport pathways of aerosol particles deposited at the drilling site of ERIC2002C during the past $50 \mathrm{yrs}$. The Climate Diagnostics Center NCEP/NCAR I (CDC-I) Meteorological Data (reproduced by the Air Resources Laboratory, NOAA) provided the global reanalysis grid data of $2.5^{\circ} \times 2.5^{\circ}$ from 1948 to date. This dataset allowed us to simulate the daily backward trajectories ending at the drilling site during 1951-2002 (normally including 365 trajectories each year), when covered the whole depositing period of ERIC2002C. The clustering tool integrated in the model was applied to form clusters of trajectories based on the percent change in total space variance (TSV) and calculate the mean backward trajectories of all the clusters each year. Generally, 2 clusters (in a few years were 3 or more) each year could be derived directly from the HYSPLIT model, and one was the transport by the westerly, and the other was the transport by the Indian summer monsoon. Taking the case in 2001 for example, $T_{-} 1$ represented the transport of relatively longer distance and higher elevation by the westerly dominantly distributed in the non-monsoon season of 2001, while T_2 represented the transport of shorter distance and lower elevation by the Indian summer monsoon dominantly distributed in the monsoon season of 2001 (Fig. 6). We counted the number of the trajectories contained in the non-long-distance backward trajectory (T_2) each year, and obtained a time series of the numbers of the trajectories in T_2 from 1951-2001. Co-variability was found between these numbers and estimated atmospheric BC concentrations over the ERG, and the correlation coefficient between them was $0.435(N=51$, $\alpha=0.01$ ) (Fig. 7), suggesting BC transported from South Asia via the Indian summer monsoon dominated the varying trend of its concentrations recorded in ERIC2002C, which could also be illustrated by the seasonal cycle of BC concentrations recorded in the 2000-2001 part of ERIC2002C with a relatively higher time resolution.

3.4 The enhanced radiative forcing caused by BC during recent decades and its climatic implications

$\mathrm{BC}$ particles could form forcing on climate by acting as the absorber of solar radiation, warming ambient atmosphere when suspending in the atmosphere, and darkening snow/ice surface and accelerating their melting when deposited in snow/ice. In old melting snow, $20 \mu \mathrm{g} \mathrm{kg}^{-1}$ of BC could reduce albedo by 0.02 and $50 \mu \mathrm{g} \mathrm{kg}^{-1}$ of BC by 0.04 (Warren and Wiscombe, 1985). A result revealed by a numeric simulation suggested atmospheric BC of $40-100 \mathrm{ng} \mathrm{m}^{-3}$ over the Arctic could accelerate the melting of ice significantly (Koch and Hansen, 2005). The estimated average atmospheric BC concentration over the ERG was nearly $80 \mathrm{ng} \mathrm{m}^{-3}$ during the past 50 yrs. Contrastively the atmospheric BC over the ERG
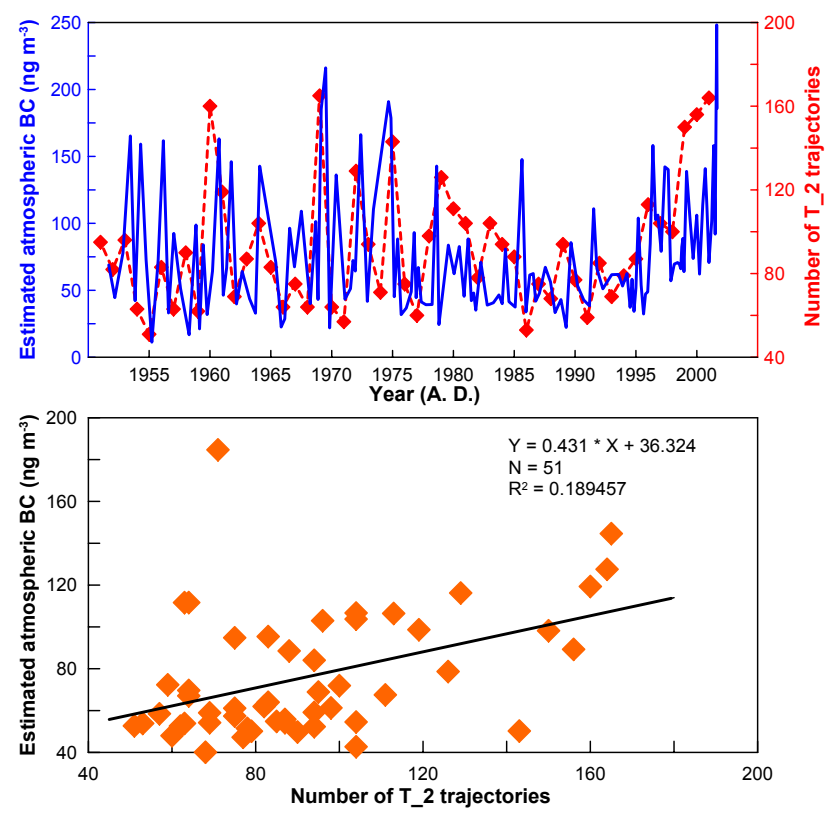

Fig. 7. The co-variability of the estimated atmospheric BC concentrations and the yearly numbers of trajectories contained in $\mathrm{T} \_2$ covering the period of 1951-2001 based on the results output from the HYSPLIT model (the top plot). Good positive correlation between them (the bottom plot) indicated the BC emissions from South Asia had significant impacts on the BC deposition in the ERG.

could not be neglected to consider the consequent climate effect after taking its enhancing the solar absorption for the atmosphere and snow/ice surface in the glacier into account.

A simulation estimated that South Asia's atmosphere had been warmed by $0.25^{\circ} \mathrm{C}$ per decade since 1950 due to BC in the haze on the south slope of the Himalayas at the altitudes ranging from 2000 to $5000 \mathrm{~m}$ a.s.l. - precisely the height where thousands of Himalayan glaciers are located, and this amplitude of warming might be sufficient to account for the observed retreats of the Himalayan glaciers (Ramanathan et al., 2007). Present-day radiative forcing from $\mathrm{BC}$ in snow was simulated by the Snow, Ice, and Aerosol Radiative (SNICAR) model based on BC emission inventory data (Bond et al., 2004; Van der Werf et al., 2006), suggesting the greatest instantaneous forcing appeared over the TP with the average of $1.5 \mathrm{~W} \mathrm{~m}^{-2}$, even exceeding $20 \mathrm{~W} \mathrm{~m}^{-2}$ in some places during spring (Flanner et al., 2007). We input the BC concentrations in ERIC2002C as a parameter into the SNICAR model to simulate the 50-year radiative forcing caused by BC in the surface of the ERG during 1951-2001. The radiative forcing (smooth average) fluctuated at $1 \mathrm{~W} \mathrm{~m}^{-2}$ during 1951-1965, approached $2 \mathrm{~W} \mathrm{~m}^{-2}$ around 1971, and then kept low and stable at $1 \mathrm{~W} \mathrm{~m}^{-2}$ during 1975-1990. And a significant increasing trend of the radiative forcing (smooth average) could be seen since 1990, which even exceeded $4.5 \mathrm{~W} \mathrm{~m}^{-2}$ in the summer of 2001 (Fig. 8). Since the 1960s, the average retreat rates of the glaciers on the north slope of 


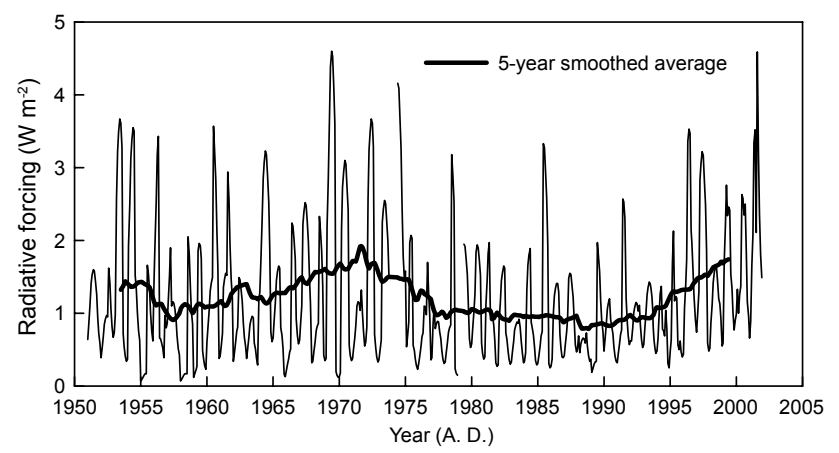

Fig. 8. Radiative forcing caused by BC depositions in the ERG simulated by the SNICAR model.

Mt. Qomolangma and of those on Mt. Xixiabangma (Fig. 1) were 5.5-9.5 $\mathrm{m} \mathrm{a}^{-1}$ and $4.0-5.2 \mathrm{~m} \mathrm{a}^{-1}$, respectively (Ren et al., 2006). And the Dasuopu ice core records from Mt. Xixiabangma suggested a weakening of the Indian summer monsoon since the 1920s should be responsible for the declining net accumulating rate of the Dasuopu glacier (Duan et al., 2004). We suggested BC particles in the atmosphere and the surface snow of Himalayan glaciers might be another potential factor to reduce the net accumulation, as well as the weakening of the monsoon.

\section{Conclusions}

$\mathrm{BC}$ concentrations were continuously measured based on a 50-year ice core (ERIC2002C) retrieved from the ERG in the northeast saddle of Mt. Qomolangma. The general varying trend of $\mathrm{BC}$ concentrations indicated a significant increase since the mid-1990s, and the seasonal cycles of BC concentrations suggested $\mathrm{BC}$ concentration level in monsoon seasons was higher than that in non-monsoon seasons. The estimated atmospheric BC concentrations over the ERG during the past $50 \mathrm{yrs}$ showed similar varying trend with that in ice, and the average was about $80 \mathrm{ng} \mathrm{m}^{-3}$. The transports of BC in the ERG simulated by the HYSPLIT model indicated that South Asia's BC emissions in monsoon seasons dominated the varying trend of $\mathrm{BC}$ concentrations in ERIC2002C. And it was suggested BC from South Asia's emissions could penetrate into the high Himalayas, although the elevated Himalayas could block off the air masses transported from South Asia to some extent. Significant radiative forcing was caused by the $\mathrm{BC}$ in the ice core simulated by the SNICAR model. Considering BC as solar radiative absorbers both in atmosphere and in snow/ice, It was suggested that this amplitudes of $\mathrm{BC}$ concentrations in the atmosphere over the Himalayas and consequently in the ice in the glaciers could not be neglected when assessing the dual warming effects on glacier melting in the Himalayas.
Acknowledgements. We would like to thank S. Warren and the anonymous referee for their valuable comments greatly improving the paper. Also, we would like to thank M. G. Flanner for his help simulating the $\mathrm{BC}$ radiative forcing in ice using the SNICAR model, and Y. Liu, Y. Wang, and Z. Geng for their help in preparing the samples at the SKLCS and K. Oikonomou at the LSCE for assisting in analyzing the samples. This work was supported by the National Basic Research Program of China (2007CB411503), the Chinese Academy of Sciences (KZCX3-SW-344), the National Natural Science Foundation of China (90411003), and the Opening Fund of the SKLCS (2007-2009). In France, it benefited from funding support from the Direction des Relations Europeennes et Internationales of the Centre National de Recherche Scientifique (CNRS), through the Programme International de Cooperation Scientifique (PICS) project "Climate and Environment in Antarctica and the Himalayas" (CLEAH, 3299). Additional support was provided by the French embassy in China.

Edited by: T. Kirchstetter

\section{References}

Bond, T. C., Streets, D. G., Yarber, K. F., Nelson, S. M., Woo, J., and Klimont, Z.: A technology-based global inventory of black and organic carbon emissions from combustion, J. Geophys. Res., 109, D14203, doi:10.1029/2003JD003697, 2004.

Bond, T. C., Bhardwaj, E., Dong, R., Jogani, R., Jung, S., Roden, C., Streets, D. G., and Trautmann, N. M.: Historical emissions of black and organic carbon aerosol from energy-related combustion, 1850-2000, Global Biogeochem. Cycles, 21, GB2018, doi:10.1029/2006GB002840, 2007.

Bryson, R. A.: Airstream climatology of Asia, in: Proceedings of the International Symposium on the Qinghai-Xizang Plateau and Mountain Meteorology, American Meteorological Society, Boston, MA, USA, pp. 604-617, 1986.

Cachier, H., Brémond, M. P., and Buat-Ménard, P.: Determination of atmospheric soot carbon with a simple thermal method, Tellus, 41B(3), 379-390, 1989.

Cachier, H. and Pertuisot, M. H.: Particulate carbon in Arctic ice, Analysis Magazine, 22, 34-37, 1994.

Chýlek, P., Srivastava, V., Cahenzli, L., Rinnick, R. G., Dod, R. L., Novakov, T., Cook, T. L., and Hinds, B. D.: Aerosol and Graphitic Carbon Content of Snow, J. Geophys. Res., 92, 98019809, 1987.

Chýlek, P., Johnson, B., Damiano, P. A., Taylor, K. C., and Clement, P.: Biomass burning record and black carbon in the GISP2 ice core, Geophys. Res. Lett., 22(2), 89-92, 1995.

Clarke, A. D. and Noone, K. J.: Soot in the Arctic snowpack: A cause for perturbations in radiative transfer, Atmos. Environ., 19, 2045-2053, 1985.

Croft, B., Lohmann, U., and von Salzen, K.: Black carbon ageing in the Canadian Centre for Climate modelling and analysis atmospheric general circulation model, Atmos. Chem. Phys., 5, 19311949, 2005, http://www.atmos-chem-phys.net/5/1931/2005/.

Davidson, C. I., Jaffrezo, J. L., Mosher, B. W., Dibb, J. E., Borys, R. D., Bodhaine, B. A., Rasmussen, R. A., Boutron, C. F., Gorlach, U., Cachier, H., Ducret, J., Colin, J. L., Heidam, N. Z., Kemp, K., and Hillamo, R.: Chemical constituents in the air and snow 
at Dye 3, Greenland: II. Analysis of Episodes in April 1989, Atmos. Environ., 27(A), 2723-2738, 1993.

Draxler, R. R. and Hess, G. D.: An overview of the HYSPLIT 4 modelling system for trajectories, dispersion, and deposition, Aust. Meteorol. Mag., 47, 295-308, 1998.

Duan, K., Yao, T., and Thompson, L. G.: Low-frequency of southern Asian monsoon variability using a 295-year record from the Dasuopu ice core in the central Himalayas, Geophys. Res. Lett., 31, L16209, doi:10.1029/2004GL020015, 2004

Flanner, M. G., Zender, C. S., Randerson, J. T., and Rasch, P. J.: Present-day climate forcing and response from black carbon in snow, J. Geophys. Res., 112, D11202, doi:10.1029/2006JD008003, 2007.

Hansen, J. and Nazarenko, L.: Soot climate forcing via snow and ice albedos, Proc. Natl. Acad. Sci., 101(2), 423-428, doi:10.1073/pnas.2237157100, 2004.

Hou, S., Chappellaz, J., Jouzel, J., Chu, P. C., Masson-Delmotte, V., Qin, D., Raynaud, D., Mayewski, P. A., Lipenkov, V. Y., and Kang, S.: Summer temperature trend over the past two millennia using air content in Himalayan ice, Clim. Past, 3, 89-95, 2007 , http://www.clim-past.net/3/89/2007/.

Jacobson, M. Z.: Climate response of fossil fuel and biofuel soot, accounting for soot's feedback to snow and sea ice albedo and emissivity, J. Geophys. Res., 109, D21201, doi:10.1029/2004JD004945, 2004a.

Jacobson, M. Z.: The short-term cooling but long-term warming due to biomass burning, J. Climate, 17, 2909-2926, 2004b.

Jenk, T. M., Szidat, S., Schwikowski, M., Gäggeler, H. W., Brütsch, S., Wacher, L., Synal, H.-A., and Saurer, M.: Radiocarbon analysis in an Alpine ice core: record of anthropogenic and biogenic contributions to carbonaceous aerosols in the past (1650-1940), Atmos. Chem. Phys., 6, 5381-5390, 2006, http://www.atmos-chem-phys.net/6/5381/2006/.

Kang, S., Mayewski, P. A., Qin, D., Yan, Y., Zhang, D., and Hou, S.: Twentieth century increase of atmospheric ammonia recorded in Mt. Everest ice core, J. Geophys. Res., 107(D21), 4595, doi:10.1029/2001JD001413, 2002.

Kang, S., Mayewski, P. A., Qin, D., Sneed, S. A., Ren, J., and Zhang, D.: Seasonal differences in snow chemistry from the vicinity of Mt. Everest, central Himalayas, Atmos. Environ., 38, 2819-2829, 2004.

Koch, D. and Hansen, J.: Distant origins of Arctic black carbon: A Goddard Institute for Space Studies ModelE experiment, J. Geophys. Res., 110, D04204, doi:10.1029/2004JD005296, 2005.

Lavanchy V. M. H., Gäggeler, H. W., Schotterer, U., Schwikowski, M., and Baltensperger, U.: Historical record of carbonaceous particle concentrations from a European high-alpine glacier (Colle Gnifetti, Switzerland), J. Geophys. Res., 104(D17), 21 227-21 236, 1999.

Lelieveld, J., Crutzen, P. J., Ramanathan, V., et al.: The Indian Ocean Experiment: widespread air pollution from South and Southeast Asia, Science, 291, 1031-1036, 2001.

McConnell, J. R., Edwards, R., Kok, G. L., Flanner, M. G., Zender, C. S., Saltzman, E. S., Banta, J. R., Pasteris, D. R., Carter, M. M., and Kahl, J. D. W.: 20th-century industrial black carbon emissions altered arctic climate forcing, Science, 317, 1381-1384, 2007.

Ming, J., Zhang, D., Kang, S., and Tian, W.: Aerosol and fresh snow chemistry in the East Rongbuk Glacier on the northern slope of Mt. Qomolangma, J. Geophys. Res., 112, D15307, doi:10.1029/2007JD008618, 2007.

Nieuwolt, S. (Ed.): Tropical Climatology: An Introduction to the Climates of the Low Latitudes, John Wiley, New York, USA, pp. 277, 1977.

Noone, K. J. and Clarke, A. D.: Soot scavenging measurements in Arctic snowfall, Atmos. Environ., 22, 2773-2778, 1988.

Qin, D., Hou, S., Zhang, D., Ren, J., Kang, S., Mayewski, P. A., and Wake, C. P.: Preliminary results from the chemical records of an $80 \mathrm{~m}$ ice core recovered from the East Rongbuk Glacier, Mt. Qomolangma, Ann. Glaciol., 35, 278-284, 2002.

Ramanathan, V., Crutzen, P. J., Kiehl, J. T., and Rosenfeld, D.: Aerosols, Climate, and the Hydrological Cycle, Science, 294, 2119-2124, 2001a.

Ramanathan, V., Crutzen, P. J., Lelieveld, J., et al.: Indian Ocean Experiment: An Integrated Analysis of the Climate Forcing and Effects of the Great Indo-Asian Haze, J. Geophys. Res., 106, 28 371-28 398, 2001b.

Ramanathan, V. and Ramana, M. V.: Atmospheric Brown Clouds: long-range transport and climate impacts, EM, 28-33 December 2003.

Ramanathan, V., Ramana, M. V., Roberts, G., Kim, D., Corrigan, C., Chung, C., and Winker, D.: Warming trends in Asia amplified by brown cloud solar absorption, Nature, 448, 575-578, 2007.

Ren, J., Jing, Z., Pu, J., and Qin, X.: Glaciers variations and climate change in the central Himalaya over the past few decades, Ann. Glaciol., 43, 218-222, 2006.

Shen, Z.: The precipitation characteristic in Mt. Qomolangma region, in Scientific Report of Mount Qomolangma Region (19661968): Meteorological and Solar Radiation (in Chinese), Science Press, Beijing, China, pp. 11-20, 1975.

Tian, L., Yao, T., Schuster, P. F., White, J. W. C., Ichiyanagi, K., Pendall, E., Pu, J., and Yu, W.: Oxygen-18 concentrations in recent precipitation and ice cores on the Tibetan Plateau, J. Geophys. Res., 108(D9), 4293, doi:10.1029/2002JD002173, 2003.

Textor, C., Schulz, M., Guibert S., et al.: Analysis and quantification of the diversities of aerosol life cycles within AeroCom, Atmos. Chem. Phys., 6, 1777-1813, 2006, http://www.atmos-chem-phys.net/6/1777/2006/.

Van der Werf, G. R., Randerson, J. T., Giglio, L., Collatz, G. J., Kasibhatla, P. S., and Arellano Jr., A. F.: Interannual variability of global biomass burning emissions from 1997 to 2004, Atmos. Chem. Phys., 6, 3423-3441, 2006, http://www.atmos-chem-phys.net/6/3423/2006/.

Wake, C. P., Mayewski, P. A., Li, Z., Han, J., and Qin, D.: Modern eolian dust deposition in central Asia, Tellus, 46B, 220-233, 1994

Warren, S. G. and Wiscombe, W. J.: Dirty snow after nuclear war, Nature, 313, 467-470, 1985.

Warren, S. G. and Clarke, A. D.: Soot in the atmosphere and snow surface of Antarctica, J. Geophys. Res., 95(D2), 1811-1816, 1990.

Xiao, C., Mayewski, P. A., Qin, D., Li, Z., Zhang, M., and Yan, Y.: Sea level pressure variability over the southern Indian Ocean inferred from a glaciochemical record in Princess Elizabeth Land, east Antarctica, J. Geophys. Res., 109, D16101, doi:10.1029/2003JD004065, 2004.

Ye, D. (Ed.) and Yang, G.: The average vertical circulation over the Qinghai-Xizang Plateau, in Tibetan Plateau Meteorology (in 
Chinese), Science Press, Beijing, China, pp. 202-212, 1979.

Zhang, S., Hou, S., Ma, X., Qin, D., and Chen, T.: Culturable bacteria in Himalayan glacial ice in response to atmospheric circulation, Biogeosciences, 4, 1-9, 2007,

http://www.biogeosciences.net/4/1/2007/. 